\title{
SAPAAN NAMA DALAM RELASI KELUARGA DAN MASYARAKAT JAWA DAN FUNGSINYA DALAM PEMBELAJARAN BAHASA JERMAN
}

\author{
oleh Wening Sahayu \\ FBS Universitas Negeri Yogyakarta
}

\begin{abstract}
This article is based on a paper aiming at describing (1) a classification of greetings by name based on form and interpersonal relationship in the life of the Javanese society and family, (2) the norms used in greetings by name in interpersonal relationships within the Javanese society and family, and (3) the function of the usage of such greetings in the teaching and learning of German.

The is biased on data compiled by means of a method of listening and speaking with baiting techniques and analyzed by means of intralingual and extralingual comparative methods. To distinguish extralingual factors, a componential analysis was used. Norms of alternation and co-occurrence were also used to determine greeting alternatives.

The results are that (1) in form the greetings by name used by the subjects under study can be differentiated into phonological and syntactical ones: shortened name, name of endearment, kinship term plus name, kinship term plus profession/rank/degree plus name, nickname, and adult name, (2) the norms used are of two types, alternation and co-occurrence, and (3) a study on greetings by name in the Javanese society can function as a provider of items for comparison in a study on German and particularly for the subject matter of Kontrastive Kulturkunde.
\end{abstract}

Keywords: greetings by name, Javanese society, German

\section{A. Pendahuluan}

Dalam hubungannya dengan keberlangsungan hidup manusia, bahasa memiliki fungsi yang beragam. Salah satu fungsi tersebut adalah sebagai alat untuk menyapa. Dalam fungsi yang demikian akan muncul bentuk-bentuk sapaan yang beragam sesuai dengan budaya yang dimiliki masyarakat. Bentuk sapaan dapat berupa: 1 . Kata ganti orang: engkau, aku, 2. Nama diri, 3. Istilah kekerabatan, 4. Gelar dan pangkat, 5. Bentuk nomina pelaku, pe+verba, 6. Bentuk nomina $+\mathrm{ku}, 7$. Kata deiktis, 8 . Bentuk nomina, 9. Bentuk zero (Chaer, 1995).

Ketepatan pemilihan bentuk sapaan memiliki peran yang penting dalam menciptakan komunikasi yang harmonis. Pemilihan bentuk sapaan yang keliru dapat menciptakan hambatan dalam aktivitas interaksi sosial. Suatu tindak komunikasi dapat rusak dan tidak berlanjut lagi apabila seorang penutur menyapa lawan tutur dengan bentuk sapaan yang kurang pas. Dengan demikian, ketepatan suatu bentuk sapaan dilihat dari posisi yang dimiliki lawan tutur. Posisi yang dimaksud dapat berkenaan dengan status sosial, jabatan, pangkat, gelar, usia, jenis kelamin, kekerabatan, keakraban dan lain sebagainya. Seorang yang memiliki jabatan tinggi lebih tepat jika disapa dengan jabatannya, misal: Pak Lurah, Pak Direktur, dalam relasi yang sifatnya formal atau saat berada di lingkungan kerjanya. 
Perkecualiaan dapat terjadi, jika si pejabat meminta untuk disapa dengan tanpa menyebut jabatannya. Sapaan yang demikian (tanpa menyebut jabatan), digunakan oleh orang yang memiliki tingkat keakraban yang tinggi dengan lawan tutur.

Melalui bentuk sapaan yang tepat, suatu aktivitas komunikasi dapat berjalan dengan lancar. Bentuk sapaan yang tepat dapat menciptakan rasa nyaman, bangga, puas pada diri lawan tutur, sehingga dia merasa dihargai. Bentuk penghargaan ini menciptakan kenyamanan dan keasyikan dalam tindak komuniksi, seperti contoh berikut.

A : Putranya sekolah dimana, mbak?

B : SD Sapen. Kenapa?

A : Nggak...SD tersebut bagus. Saya sempat beberapa minggu observasi di sana. Anak-anaknya mandiri dan menikmati sekolahnya.

B : Masak? Kamu bisa aja ah!

(A seorang wanita berusia 42 tahun, yang belum begitu kenal B (37 tahun), walaupun mereka bekerja di tempat yang sama.)

Pada umumnya, seorang wanita yang berusia empatpuluhan atau di bawahnya lebih senang disapa 'mbak', daripada 'ibu', walaupun dia telah berkeluarga dan memiliki anak. Bentuk sapaan 'mbak' dapat menciptakan persepsi bahwa yang menjadi lawan tutur masih berusia muda daripada bentuk sapaan 'bu' atau 'ibu'. Selain itu, bentuk sapaan 'mbak' terkesan lebih akrab daripada 'bu'. Oleh karenanya, dengan melalui bentuk sapaan 'mbak' akan menciptakan rasa nyaman pada lawan tutur, sehingga aktivitas komunikasi dapat berjalan lebih akrab.

Dalam kehidupan sehari-hari, bentuk sapaan dapat berupa nama. Pilihan sapaan dalam bentuk nama dapat berupa nama pertama, atau gelar diikuti nama akhir (Brown \& Ford,1972). Konsep tersebut nampaknya kurang mewadai ragam bentuk sapaan nama yang ada di masyarakat Jawa. Dalam masyarakat Jawa, selain nama pertama, gelar + nama akhir, masih terdapat bentuk-bentuk sapaan nama yang lain. Contoh: mbak/mas + nama awal/akhir/panggilan/ringkas, nama julukan, nama kecil, nama sayang dan lain sebagainya. Tulisan ini akan membahas sapaan nama dalam relasi keluarga dan masyarakat Jawa, khususnya yang ada di Perumahan Purwomartani Baru Yogyakarta. Observasi dilakukan dari bulan September sampai dengan bulan Desember 2006. Namun demikian untuk memperkaya data, sapaan nama yang secara umum dikenal masyarakat Jawa juga akan diungkapkan dalam makalah ini. Seperti diketahui bahwa masyarakat Jawa di Yogyakarta dapat dikategorikan sebagai masyarakat bilingual. Mereka memiliki kemampuan berbahasa Jawa dan Indonesia. Bahkan, selain kedua bahasa tersebut, sebagian masyarakat Jawa di Yogyakarta menguasai salah satu bahasa asing (multilingual). Dalam tulisan ini bahasa yang diamati untuk mengetahui bentuk sapaan yang dipakai masyarakat Jawa adalah hanya bahasa Jawa. Data dijaring dengan menggunakan metode simak dan cakap dengan teknik pancing. Untuk menganalisis data digunakan metode padan interlingual dan ekstralingual. Untuk membedakan faktor-faktor yang berkaitan dengan ekstralingual digunakan analisis komponen. Kaidah alternasi dan kookurensi juga digunakan dalam menganalisis bentukbentuk sapaan.

Permasalahan yang akan dikupas dalam tulisan ini dapat dirumuskan sebagai berikut: (1) Bagaimanakah penggolongan sapaan berdasarkan bentuk dan relasi dalam kehidupan keluarga dan masyarakat Jawa? (2) Bagaimanakah kaidah pemakaian sapaan dalam kehidupan keluarga dan masyarakat Jawa? (3) Bagaimana fungsi sapaan dalam kehidupan keluarga dan masyarakat Jawa dalam pembelajaran bahasa Jerman?

Tujuan tulisan ini adalah sebagai berikut: (1) Mendeskripsikan penggolongan sapaan berdasarkan bentuk dan relasi dalam kehidupan keluarga dan masyarakat Jawa, (2) Mendeskripsikan kaidah pemakaian sapaan dalam kehidupan keluarga dan masyarakat Jawa, (3) Mendeskripsikan fungsi pemakaian 
sapaan dalam kehidupan keluarga dan masyarakat Jawa dalam pembelajaran bahasa Jerman.

Kajian mengenai sapaan nama dalam masyarakat Jawa ini dapat memberikan tambahan wawasan bagi para pembaca pada umumnya, dan para pemerhati sosiolinguistik pada khususnya tentang bentuk sapaan nama dalam relasi keluarga dan masyarakat. Selain itu, kajian ini dapat dimanfaatkan sebagai materi pembanding dalam pembelajaran bahasa Jerman, khususnya dalam mata kuliah Kontrastive Kulturkunde.

\section{B. JENIS SAPAAN}

Chao (dalam Wijana, 1991) mengungkapkan bahwa penggunaan bahasa yang benar bukan semata-mata bersandar pada kebenaran gramatikal, namun lebih pada bagaimana bahasa itu digunakan secara benar dalam konteks sosial masyarakat pengguna bahasa. Sapaan yang merupakan salah satu perangkat bahasa yang digunakan untuk menunjuk seseorang dalam interaksi sosial, semestinya pemakaiannya juga mengacu pada konteks sosial masyarakat pengguna bahasa. Kesalahan dalam pemakaian sapaan dapat menumbuhkan rasa yang tidak nyaman bagi lawan tutur, bahkan dapat membuatnya enggan meneruskan pembicaraan, seperti contoh berikut ini.

A : Siapa namamu, $n d u k$ ?

B : ???? (tidak menjawab, berjalan ke arah ibunya dan mengadu: masak aku dipanggil nduk, emangnya babu!)

Percakapan tersebut terjadi di acara arisan suatu kantor yang anggotanya cukup heterogen, tidak hanya dari etnis jawa. Anak yang berusia sekitar lima tahunan tsb merasa tidak senang dengan bentuk sapaan ' $n d u k$ ' yang diberikan kepadanya, karena di lingkungan keluarganya ' $n d u k$ ' dipakai untuk menyapa pembantu. 'Nduk' dipersepsikan oleh anak kecil yang lahir di Jakarta tersebut sebagai panggilan khusus untuk pembantu, sehingga merasa kurang senang jika dirinya juga dipanggil ' $n d u k$ '. Padahal, bagi penyapa tersebut, 'nduk' merupakan bentuk sapaan masyarakat Jawa yang lazim digunakan untuk menyapa anak perempuan. Sebagai seorang yang berlatarbelakang budaya Jawa, penyapa tersebut memilih bentuk sapaan sesuai yang dipahaminya, tanpa melihat konteks sosial (terutama latar belakang sosial) yang dimiliki anak kecil tersebut.

Contoh lain dari bentuk sapaan yang ada dalam masyarakat Jawa adalah sebagai berikut.
A : Saka ngendi,An?
'Darimana, An?'
B : Ki lho tuku mie gorenge Parmi.
'Nih lho beli mie gorengnya Parmi'.
A : Parmi gendutya?
'Parmi gemuk ya?'
B : Dudu, Parmi jlitheng.
'Bukan, Parmi hitam'

Sapaan yang digunakan oleh A maupun $\mathrm{B}$ untuk menunjuk orang ketiga yang bernama Parmi tidak cukup hanya dengan sapaan nama 'Parmi', namun dilengkapi dengan julukan yang melekat pada masing-masing individu yang bernama Parmi tersebut. Dari dialog tersebut diketahui ada dua orang penjual nasi goreng yang bernama Parmi dan untuk membedakan keduanya dilekatkanlah julukan pada nama Parmi. Julukan tersebut mengacu pada keadaan fisik yang dimiliki masingmasing penjual nasi goreng tersebut. Bentuk sapaan 'Parmi gendut' menunjukkan bahwa pemilik nama tersebut bertubuh subur atau gemuk, sedangkan 'Parmi jlitheng' mengacu pada kulit sawo matang pemiliknya.

Sistem panggilan setiap bahasa berbeda-beda, tergantung pada aspek sosiokultural masyarakat pemakai bahasa (Wardhaugh, 1992). Dalam memilih kode bahasa, termasuk sapaan, perlu mempertimbangkan lima komponen tuturan yaitu (1) siapa yang bicara, (2) dengan bahasa apa, (3) kepada siapa, (4) kapan dan dimana, (5) dengan tujuan apa (Fishman, 1972). 
Jenis-jenis sapaan diungkapkan oleh Kridalaksana (Chaer, 1995) sebagai berikut.

1. Kata ganti orang: engkau, aku

2. Nama diri

3. Istilah kekerabatan

4. Gelar dan pangkat

5. Bentuk nomina pelaku, pe+verba

6. Bentuk nomina $+\mathrm{ku}$

7. Kata deiktis

8. Bentuk nomina

9. Bentuk zero

Menurut Brown \& Ford (1972)

Pemilihan bentuk sapaan dalam suatu pertuturan didasarkan pada asas relasional. Pilihan sapaan dalam bentuk nama dapat berupa nama pertama (first name), atau gelar diikuti nama akhir (last name). Hal yang senada diungkapkan oleh Chaika (1982), bahwa sapaan merupakan bagian dari salam. Setelah seseorang mengemukakan salam biasanya dilanjutkan dengan sapaan yang dapat berupa nama kecil atau gelar diikuti nama akhir. Selanjutnya Chaika mengungkapkan perbedaan salam dan sapaan adalah: (1) sapaan dapat berubah sesuai dengan hubugan sosial antara penutur, adapun salam selalu sama tanpa tergantung siapa penuturnya, (2) sapaan digunakan untuk menunjukkan hubungan keakraban dan kekuasaan seseorang, (3) sapaan dapat diulang-ulang selama pertuturan berlangsung.

Crystall (1985) mengungkapkan cara menganalisis sapaan. Menurutnya, sapaan dapat dianalisis berdasarkan tipe-tipe penutur yang terlibat dalam suatu kegiatan pertuturan. Kaidah alternasi dan kookurensi perlu diperhatikan dalam menganalisis bentuk sapaan. Kaidah alternasi berkaitan dengan cara menentukan pilihan bentuk sapaan yang digunakan dalam pertuturan. Adapun kaidah kookurensi berkaitan dengan pilihan sapaan beserta pasangannya dalam suatu pertuturan, yang biasanya memperhatikan aspek-aspek di luar sapaan itu sendiri.

\section{PENGgolongan SAPAAN}

Sapaan nama dapat digolongkan berdasarkan bentuk dan penggunaan seharihari sebagai berikut.

\section{a. Berdasarkan bentuk}

Berdasarkan bentuknya sapaan nama dapat dilihat dari ciri fonologis dan sintaktik.

\section{1) Ciri fonologis \\ Pelesapan awal \\ $\begin{array}{ll}\text { Roswita } & \rightarrow \text { Ita } \\ \text { Herlina } & \rightarrow \text { Lina } \\ \text { Wahyudi } & \rightarrow \text { Yudi }\end{array}$ \\ Pelesapan akhir

$\begin{array}{ll}\text { Hidayat } & \rightarrow \text { Hida } \\ \text { Purwanto } & \rightarrow \text { Pur } \\ \text { Jumiati } & \rightarrow \text { Jum }\end{array}$

\section{Bentuk perulangan}

$\begin{array}{llll}\text { Fitria } & \rightarrow \mathrm{Fi} & \rightarrow \text { Fifi } \\ \text { Mutiara } & \rightarrow \mathrm{Ra} & \rightarrow \text { Rara } \\ \text { Mariana } & \rightarrow \mathrm{Na} & \rightarrow \text { Nana }\end{array}$

Dilihat dari ciri fonologisnya sapaan nama dapat berbentuk pelesapan awal, pelesapan akhir, dan perulangan. Hasil dari proses pelesapan awal, pelesapan akhir, dan perulangan adalah nama pendek yang berfungsi sebagai sarana menyapa seseorang (yang dimaksud). Berdasarkan data di atas, bentuk sapaan nama pendek ini terjadi dengan cara melesapkan suku kata awal (pelesapan awal), melesapkan satu atau dua suku kata akhir (pelesapan akhir), dan mengulang suku kata awal atau akhir (perulangan).

\section{2) Ciri Sintaktik}

\section{Distribusi sintaktik}

Bentuk sapaan nama yang terletak di depan klausa

Hid, isa ora mau ulangane?

'Hid, bisa nggak tesnya tadi?'

Vasti, mimik susu ya?

'Vasti, minum susu ya?'

Bil, siji wae ya!

'Bil, satu saja ya!' 
Bentuk sapaan nama yang terletak di belakang klausa

Jajan apa, Ca?

'Jajan apa, Ca?'

Janji lo, Da!

'Janji lo, Da!'

Piye dadine, Ron?

'Gimana jadinya, Ron?'

Dilihat dari ciri sintaktiknya sapaan nama dapat terletak di depan atau belakang klausa.

b. Berdasarkan penggunaan sehari-hari

1) Kepada kerabat (hubungan darah)

Kepada saudara perempuan bapak/ibu:

Mbak Wit, neng ngendi dhuwite?

'Mbak Wit, dimana uangnya?'

Kae lo njaluk dhewe karo tante Nuk!

'Sana lo minta uang sama tante Nuk!'

Budhe Sumi, masak apa?

'Budhe Sumi, masak apa?'

Lagi ngapa, bulik Tun?

'Lagi apa, bulik Tun?'

Sapaan nama yang digunakan untuk menyapa saudara perempuan bapak/ibu berbentuk nama ringkas yang terdiri dari satu atau dua suku kata. Nama tersebut selalu diawali bentuk sapaan kekerabatan, seperti mbak, tante, budhe, dan bulik. Dari data Kae lo njaluk dhewe karo tante Nuk! 'Sana lo minta uang sama tante Nuk' diketahui adanya bentuk mbasakke. Bentuk ini secara tidak langsung dapat difungsikan untuk mengajari anak-anak menghargai orang lain dengan cara menggunakan bentuk sapaan yang tepat.

\section{Kepada saudara laki-laki bapak/ibu:}

Om Waris, njaluk dhuwite to.

'Om Waris, minta uangnya to'

Pakde To, nyilih pompo ya.

'Pakde To, pinjam pompa ya'

Kae lo omong dhewe karo lik Mugi!
'Sana lo bilang sendiri pada lik Mugi!'

Mas Yanto, aku lagi ana masalah.

'Mas Yanto, aku baru ada masalah'

Sapaan nama yang digunakan untuk menyapa saudara laki-laki bapak/ibu berbentuk nama ringkas yang terdiri dari satu atau dua suku kata. Nama tersebut selalu diawali bentuk sapaan kekerabatan, seperti mas, om, pakde, dan lik (paklik). Dari data Kae lo omong dhewe karo lik Mugi! 'Sana lo bilang sendiri pada lik Mugi!' diketahui adanya bentuk mbasakke.

\section{Kepada kakek/nenek:}

Mbah Mul, kapan teka?

'Mbah Mul, kapan datang?'

Iki piye carane, mbah $\mathrm{Na}$ ?

'Ini gimana caranya, Mbah $\mathrm{Na?}$

Sapaan nama yang digunakan untuk menyapa kakek/nenek diawali dengan bentuk sapaan kekerabatan mbah atau simbah. Masyarakat Jawa juga memiliki bentuk sapaan kekerabatan eyang.

\section{Kepada anak}

$\mathrm{Da}$, ayo sinau!

'Da, ayo belajar!'

Nulis apa, Ca?

'Nulis apa, Ca?'

Mbak Caca, cepet to maeme!

'Mbak Caca, cepet to makannya!'

Mas Jati maeme ra diemut to!

'Mas Jati makannya jangan dikulum to!'

Bimo ki ngono lo karo adhike.

'Bimo tuh gitu lo sama adiknya'

Dede, wis maem?

'Dede, sudah makan?'

Dik Hida, isa ra mau?

'Dik Hida, bisa tidak tadi?'

Dik Ca, bobo' yuk?

'Dik Ca, tidur yuk?'

Cayatu, gemes ibuk.

'Cayatu, gemas ibu' 
Sapaan nama yang digunakan untuk menyapa anak berbentuk nama ringkas yang terdiri dari satu atau dua suku kata. Nama tersebut tanpa atau diawali bentuk sapaan kekerabatan, seperti dik, mas, mbak, dede'. Dari data di atas diketahui adanya bentuk sapaan sayang kepada anak, yaitu cayatu (dari Zahraku).

\section{Kepada cucu}

Mas Imron, hayo adus dhisik!

'Mas Imron, ayo mandi dulu!'

Nin, piye sekolahe?

'Nin, gimana sekolahnya?'

Sapaan nama yang digunakan untuk menyapa cucu tanpa atau diawali dengan bentuk sapaan kekerabatan.

\section{2) Kepada Kerabat (tali perkawinan)}

Kepada suami/istri

Make Ranti mesti ngoten, bu!

'Maknya Ranti pasti gitu, bu!'

Bapake Dwik ki mesti ngono, ra tau ora!

'Bapaknya Dwik tuh pasti gitu, tidak pernah tidak!'

Sapaan nama yang digunakan untuk menyapa suami/istri menggunakan nama anak, biasanya anak pertama. Nama tersebut selalu diawali bentuk sapaan kekerabatan seperti bapak/ibu/mak + bentuk posesif/kepemilikan.

\section{Kepada saudara ipar/pasangannya}

Dadine pira ki, mas Agus?

'Jadinya berapa ini, mas Agus?'

Mbak Ning to sing arep rono?

'Mbak Ning kan yang mau ke sana?'

Wah tambah makmur ki, pakdhe To!

'Wah tambah makmur nih, pakdhe To!'

Sapaan nama yang digunakan untuk menyapa saudara ipar atau pasangannya diawali dengan bentuk sapaan kekerabatan mbak, mas, dik diikuti nama. Dari data Wah tambah makmur ki, pakdhe To! 'Wah tambah makmur nih, pakdhe To!' diketahui adanya bentuk mbasakke. Bentuk sapaan kekerabatan pakde lazimnya digunakan oleh seseorang keponakan (anak saudara kandung) kepada kakak laki-laki dari orang tuanya.

\section{3) Kepada bukan kerabat} Kepada anak kecil

Maem apa, Ca?

'Makan apa, Ca?'

Mbak Ca, rambute apik he.

'Mbak Ca, rambutnya bagus'.

Maem mie, dik $\mathrm{Ca}$ ?

'Makan mie, dik Ca?'

Dik Gifar nderek bu Agus yuk?

'Dik Gifar ikut bu Agus yuk?'

Sapaan nama pada anak kecil yang bukan kerabat bisa berupa nama saja atau sapaan kekerabatan (dik/mas/mbak)+nama. Berdasarkan data di atas pemilihan sapaan kekerabatan tersebut tidak didasarkan pada umur anak yang disapa. Anak laki-laki yang berumur tiga tahunan bisa disapa dengan mas+nama, dan untuk anak perempuan dengan bentuk sapaan mbak+nama. Hal ini berbeda dengan bentuk sapaan nama kepada kerabat, yang pemilihannya cenderung didasarkan pada posisi kekerabatan atau awu anak yang disapa dan penyapa.

\section{Kepada remaja}

Mas Bimo, adike ning ndalan lo.

'Mas Bimo, adiknya di jalan lo'.

Piye Da, seneng ra sekolah kana?

'Gimana Da, senang nggak sekolah di sana?'

Juara pira Odi?

'Juara berapa Odi?' 
Sapaan nama pada anak remaja yang bukan kerabat bisa berupa nama saja atau nama dengan didahului sapaan kekerabatan seperti dik, mas, dan mbak. Sama halnya dengan fenomena sapaan nama pada anak kecil yang bukan kerabat. Berdasarkan data di atas pemilihan sapaan kekerabatan tersebut tidak didasarkan pada umur anak yang disapa. Remaja laki-laki bisa disapa dengan dik/mas+nama, dan untuk remaja perempuan dengan bentuk sapaan dik/mbak+nama. Hal ini berbeda dengan bentuk sapaan nama kepada kerabat, yang pemilihannya cenderung didasarkan pada posisi kekerabatan atau $a w u$ anak yang disapa dan penyapa.

\section{Kepada orang dewasa (dalam situasi non formal)}

Mbak Nana, saiki kerja ning ngendi?

'Mbak Nana, sekarang kerja dimana?'

Bu Yudi, aku titip anakku yo, dhilit.

'Bu Yudi, aku titip anakku ya, sebentar'

Mas Yono, tulung iki yo!

'Mas Yono, tolong ini ya!'

Dokter Irma, dos pundi tekanan darahipun?

'Dokter Irma, gimana tekanan darahnya?'

Dari data di atas sapaan nama pada orang dewasa berbentuk sapaan kekerabatan+ nama atau profesi (dokter)+nama.

\section{Kepada orang dewasa (dalam situasi formal)}

Bapak Drs. Farids ingkang kawula hormati......

'Bapak Drs. Farids yang saya hormati....'

Bapak ustadz Suryadi ingkang sampun rawuh .......

'Bapak ustadz Suryadi yang sudah datang.......'

Ibu ustadzah Astuti mugi kersa rawuh malih........

'Ibu ustadzah Astuti semoga mau datang lagi........'
Ibu dokter Irma, ingkang kersa rawuh.......

'Ibu dokter Irma, yang mau datang.......'

Dari data di atas sapaan nama pada orang dewasa pada situasi formal berbentuk sapaan kekerabatan+nama atau sapaan kekerabatan+ profesi/gelar+nama. Pada data di atas terlihat bahwa dalam situasi formal bentuk sapaan kekerabatan seperti ibu/bapak selalu dipakai, diikuti nama atau profesi/gelar+nama.

\section{c. Nama Julukan}

Selain nama gelar yang dipakai oleh kalangan bangsawan atau nama lahir yang tertera pada KTP, pada masyarakat Jawa terdapat pula bentuk nama yang lain, antara lain nama julukan dan nama tua. Nama julukan biasanya berfungsi untuk membedakan orang yang memiliki nama yang sama. Dalam fungsi yang demikian, nama tersebut dikaitkan dengan keadaan fisik orang yang memiliki nama tersebut. Contoh: Warno Tembong dan Warno Cengkring. Dari nama ini dapat diprediksi bahwa orang yang mendapat julukan 'Warno Tembong' memiliki tanda lahir jenis tembong (biasanya berbentuk bercak biru/merah di kulit) yang dapat dilihat orang lain, sedangkan orang yang mendapat julukan 'Warno Cengkring' biasanya memiliki tubuh yang kurus atau cengkring.

Selain berfungsi untuk membedakan orang yang bernama sama, nama julukan juga memiliki fungsi mengidentifikasi profesi, kemampuan atau prestasi yang pernah diraih seseorang. Contoh: Srimi Jamu, Wira Empu, dan Trimo Sekak. 'Srimi Jamu' ditujukan pada seseorang yang memiliki nama Srimi yang memiliki profesi atau kemampuan dalam meramu jamu. Julukan 'Wira Empu' mengidentifikasikan bahwa seseorang yang dimaksud memiliki keahlian membuat keris. Adapun 'Trimo Sekak' memberikan petunjuk bahwa seseorang yang memiliki julukan tersebut 
lihai atau bahkan pernah memiliki prestasi dalam bidang catur.

\section{d. Nama Tua}

Nama tua adalah nama yang biasanya disandang seseorang setelah menikah. Untuk perempuan nama tua diambil dari nama suami. Setelah menyandang nama suami, secara otomatis sapaan nama yang ditujukan kepadanya adalah nama suami. Hanya lingkungan keluarga dan teman dekat yang tetap menyapa dengan nama lahir (nama lajang). Contoh, seorang perempuan yang bernama 'Retno' yang menikah dengan seorang laki-laki yang bernama 'Purwacaraka', biasanya akan menyandang nama baru yaitu 'Retno Purwacaraka'. Selanjutnya, perempuan tersebut akan disapa 'bu Pur'.
Untuk laki-laki nama tua diambil dari nama orang tua laki-laki (bapak). Dengan demikian dapat dikatakan bahwa nama tua dapat bersifat turun-temurun. Namun demikian, terdapat juga nama tua yang tidak diambil dari nama orang tua. Hal ini disebabkan orang tuanya tidak memiliki nama tua, atau nama yang dimilikinya dianggap kurang prestisius di masa sekarang.

Fenomena yang muncul di masyarakat sekarang ini terkait dengan nama tua adalah bahwa generasi sekarang sangat jarang menggunakan nama tua setelah dia menikah.

\section{ANALISIS KOMPONENSIAL BENTUK SAPAAN NAMA}

\begin{tabular}{|l|c|c|c|c|c|c|}
\hline \multicolumn{1}{|c|}{ SAPAAN NAMA } & F & L & D & K & Kr & A \\
\hline Nama ringkas/panggilan(Da, Ca, Fi) & - & \pm & \pm & \pm & \pm & + \\
\hline $\begin{array}{l}\text { Sapaan kekerabatan + nama ringkas/panggilan } \\
\text { (Mbak Ca, Tante Nuk, mbah Mul, dll) }\end{array}$ & - & \pm & \pm & \pm & \pm & + \\
\hline $\begin{array}{l}\text { Sapaan kekerabatan + nama depan/ belakang } \\
\text { (Om Waris, Mas Yanto, mbah Slamet, dll) }\end{array}$ & \pm & \pm & \pm & \pm & \pm & \pm \\
\hline Profesi+nama (Dokter Irma) & \pm & \pm & + & \pm & - & - \\
\hline $\begin{array}{l}\text { Sapaan kekerabatan +gelar/jabatan/profesi+nama depan } \\
\text { (belakang(Bapak Drs. Farids, Bapak Ustadz Suryadi, dll.) }\end{array}$ & + & \pm & + & \pm & - & - \\
\hline Nama sayang (Cayatu, dari Zahraku) & - & \pm & - & - & + & + \\
\hline $\begin{array}{l}\text { Nama julukan } \\
\text { Nama Tua }\end{array}$ & - & \pm & \pm & \pm & - & \pm \\
\pm
\end{tabular}

Keterangan:

$\mathrm{F}$ : formal

L : laki-laki

D : dewasa

$\mathrm{K}$ : kawin

Kr. : kerabat

A : akrab 


\section{E. KAIDAH ALTERNASI DAN KOOKURENSI}

1. Kaidah alternasi berdasarkan usia orang yang disapa

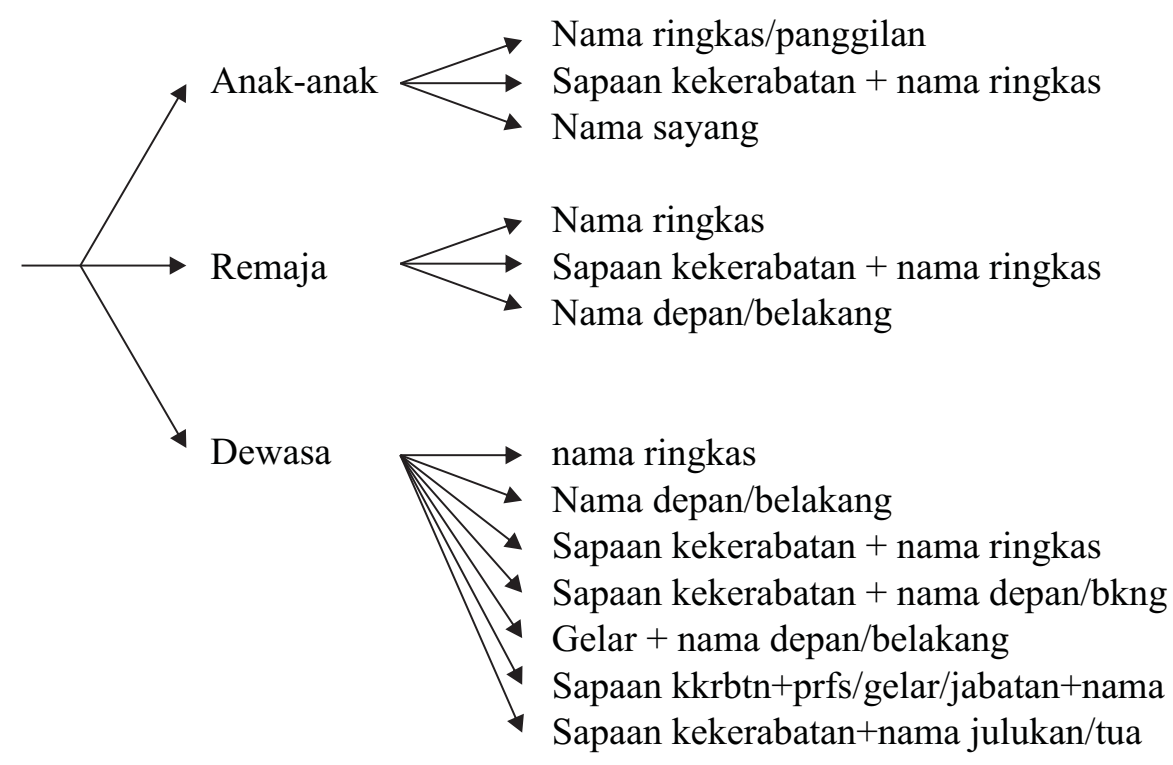

\section{Kaidah Kookurensi}

Berdasarkan kaidah ini dapat diprediksikan beberapa sapaan yang akan digunakan seorang penyapa kepada lawan tuturnya. Sapaan nama ringkas untuk orang dewasa hanya akan dipakai oleh orang yang memiliki hubungan kekerabatan atau yang memiliki keakraban yang cukup tinggi dengan lawan tutur. Dari segi kekuasan, sapaan nama panggilan/ringkas hanya akan dipakai oleh orang yang lebih tua atau sebaya, baik sapaan pada anak-anak, remaja, maupun dewasa.

Dilihat dari segi keformalan saat tuturan berlangsung, sapaan dengan pola sapaan kkrbtn+profesi+nama dpn/blkng, dan sapaan kkrbtn+jabatan+nama dpn, dan sapaan kkrbtn+gelar+nama dpn/blkng hanya dipakai dalam situasi formal.

F. F U N G S I SA PA A N N A M A MASYARAKAT JAWA DALAM PEMBELAJARAN BAHASAJERMAN

Dalam Kurikukum 2004 yang digunakan acuan dalam penyelenggaraan perkuliahan di Prodi Pendidika Bahasa Jerman, Fakultas Bahasa dan Seni, Universitas Negeri Yogyakarta terdapat beberapa mata kuliah yang bermuatan budaya Jerman, antara lain mata kuliah Kontrastive Kulturkunde. Mata kuliah ini terbagi dalam tiga tingkatan, yaitu Kontrastive Kulturkunde I, II, dan III. Berdasarkan deskripsinya, salah satu tujuan diselenggarakannya mata kuliah ini adalah berkembangnya sisi kognitif mahasiwa, khususnya yang berkaitan dengan pemahaman budaya bangsa Jerman. Adapun pada sisi afektif, melalui mata kuliah ini mahasiswa dapat menghargai dan mencintai budaya bangsa sendiri dan budaya bangsa lain. Dan selanjutnya diharapkan mahasiswa dapat memetik hal-hal yang positif yang terkandung dalam budaya yang dimiliki bangsa Jerman.

Dalam mata kuliah ini, perbandingan budaya yang dimiliki bangsa Jerman dan Indonesia dijadikan salah satu cara untuk menumbuhkan pemahaman mahasiswa akan budaya bangsa Jerman. Terkait dengan hal ini, maka kajian mengenai sapaan nama masyarakat Jawa dapat berfungsi sebagai materi pembanding yang sangat menarik dalam 
mata kuliah Kontrastive Kulturkunde I, yang salah satu materinya membahas sapaan dalam bahasa Jerman.

\section{G. PENUTUP}

Beberapa kesimpulan dapat dirumuskan sebagai berikut.

1. Bentuk sapaan nama di desa Purwomartani, khususnya yang digunakan masyarakat di perumahanan Purwomartani Baru, dapat dibedakan ke dalam dua jenis, yaitu berdasarkan ciri fonologis dan ciri sintaktik.

2. Bentuk sapaan nama dapat berupa nama ringkas, nama sayang, sapaan kekerabatan + nama, sapaan kekerabatan + profesi/ jabatan/gelar + nama, nama julukan dan nama tua.

3. Kaidah sapaan dibedakan menjadi dua jenis, yaitu kaidah alternasi dan kookurensi. Kaidah alternasi berkaitan dengan pilihan bentuk sapaan nama.. Adapun kaidah kookurensi melihat faktorfaktor di luar sapaan yang menyertai sapaan nama tersebut.

4. Kajian mengenai sapaan nama masyarakat Jawa dapat berfungsi sebagai materi pembanding dalam pembelajaran bahasa Jerman, khususnya untuk mata kuliah Kontrastive Kulturkunde I.

\section{DAFTAR PUSTAKA}

Brown, R \& M. Ford. 1972. "Adress in American English”, den Laver, J. (Ed.): Communication in Face to Face Intersection. Ringwood: Penguin Book, Inc.

Chaika, Elaine. 1982. Language the Social Mirror. London: Newburg House Publisher Inc.

Chaer, Abdul. 1994. Tata Bahasa Praktis Bahasa Indonesia. Jakarta: Bhratara.

Chrystal David. 1991. A Dictionary of Linguistics and Phonetics. Massachusett: Basil Blackwell.
Fishman, J.A. 1972. "The Sociology of Language" dalam Pier Paolo Giglioli (ed). Language and Social Context. England: Penguin Books.

Firts, J.R. 1964. On Sociological Linguistic. "Cultural and Society". Dell Hymes (Ed.) Harper and Row Publisher.

Hymes, Dell. 1989. Foundations in Sociolinguistic. An Ethnographic Approach. Philadelphia: University of Pennsylvania Press.

Pateda, Mansoer. 1992. Sosiolinguistik. Bandung: Angkasa.

Sudaryanto. 1993. Metode dan Teknik Analisis Bahasa: Pengantar Penelitian Wahana Kebudayaan secara Linguistik. Yogyakarta: Duta Wacana University Press.

Wijana, I Dewa Putu. 1991. "The Use of Term Address in Bahasa Indonesia". Faculty of Letters. Yogyakarta: Gadjah Mada University Press. .2004. "Teori Kesantunan dan Humor. Makalah Seminar Nasional Semantik III. Pragmatik dan Makna Interaksi Sosial. Surakarta 228 Agustus.

Wardhaugh, Ronald. 1992. An Introduction to Sociolinguistics. Cambridge: Blackwell. 